\title{
EFEKTIFITAS TERAPI MOXA DAN HYPNOBIRTHING UNTUK PERBAIKAN LETAK SUNGSANG PADA IBU HAMIL TRIMESTER III
}

\author{
${ }^{1)}$ Dede Waslia ${ }^{2)}$ Nanik Cahyati \\ Program Studi Kebidanan (D-3), Stikes Jenderal Achmad Yani Cimahi \\ Jl. Terusan Jend. Sudirman- Cimahi- Jawa Barat- Indonesia \\ E-mail : ${ }^{1)}$ dedewaslia@gmail.com, ${ }^{2)}$ nanikcahyati3@gmail.com
}

\section{Kata Kunci:}

Kehamilan, Sungsang, Terapi, Moxa, Hypnobirthing, Eksperimen murni

\section{Keywords:}

Breech Pregnancy, Moxa Therapy, Hypnobirthing, Pure Experimentation

\section{Info Artikel}

Tanggal dikirim: 25-11-2020

Tanggal direvisi: 13-1-2021

Tanggal diterima: 1-12-2020 DOI Artikel:

10.36341/jomis.v5i1.1542

Creative Commons AttributionNonCommercial-ShareAlike 4.0 International License.

\begin{abstract}
ABSTRAK
Kehamilan sungsang termasuk kedalam penyulit kehamilan yang dapat menyebabkan risiko morbiditas dan mortalitas yang tinggi pada ibu dan janin. Di Indonesia 10\% operasi caesar dilakukan pada ibu hamil dengan letak sungsang sedangkan WHO menetapkan indikator persalinan caesaria untuk setiap negara 5-15\%. Berbagai jenis manuver dipromosikan untuk mengubah letak janin dengan harapan ibu bisa melahirkan normal. Terapi moxa merupakan pengobatan Cina yang dilakukan dengan cara membakar ramuan mugwort dan didekatkan di bagian luar jari kelingking kaki dengan tujuan membantu versi pemutaran janin. Terapi Hypnobirthing membantu memberikan sugesti dan mereprograming pikiran bawah sadar yang dapat diarahkan untuk membuat perubahan dalam tubuh ibu. Pelepasan ketakutan dalam hipnobirthing membantu ibu rileks dan memungkinkan bayinya berputar. Tujuan penelitian ini untuk mengetahui efektifitas terapi moxa dan hypnobirthing serta metode yang paling efektif untuk perbaikan letak sungsang pada ibu hamil Trimester III. Metode penelitian yang digunakan eksperimen murni dengan post test control design pada 33 ibu hamil trimester III. Analisis data menggunakan uji kruskall-wallis.Hasil penelitian diperoleh bahwa terapi moxa dan hypnobirthing efektif dalam perbaikan letak sungsang dengan nilai $\mathrm{p} 0,001(\mathrm{p}<0,05)$. Terapi moxa merupakan metode yang paling efektif dengan nilai mean (25.50).Rekomendasi terapi moxa dan hypnobirthing efektif dan aman untuk membantu versi pemutaran janin pada letak sungsang.
\end{abstract}

\section{ABSTRACT}

Breech pregnancy is included in the complication of pregnancy which can cause a high risk of morbidity and mortality in the mother and fetus. In Indonesia $10 \%$ of caesarean sections are performed on pregnant women with breech location while who sets the indicator of caesarean delivery for each country 5-15\%. Various types of maneuvers are promoted to change the location of the fetus in the hope that the mother can give birth normally. Moxa therapy is a Chinese treatment that is done by burning mugwort herb and is approached on the outside of the little finger of the foot with the aim of helping the fetal screening version. Hypnobirthing therapy helps provide suggestion and reprogramming the subconscious mind that can be directed to make changes in the mother's body. The release of fear in hypnobirthing helps the mother relax and allow her baby to spin. The purpose of this study was to find out the effectiveness of moxa and hypnobirthing therapy as well as the most effective methods for improving breech location in Trimester III pregnant women. The research method used pure experimentation with post test control design in 33 pregnant women trimester III. Data analysis using kruskall-wallis test.The results of the study found that moxa therapy and hypnobirthing are effective in improving breech location with a value of $p 0.001$ ( $p<0.05)$. Moxa therapy is the most effective method with a mean value (25.50).Moxa and hypnobirthing therapy recommendations are effective and safe to help the fetal screening version at breech location. 


\section{PENDAHULUAN}

Letak sungsang merupakan kondisi dimana presentasi janin terutama kepala berada di fundus uteri dan bokong berada di bawah kavum uteri. Kehamilan sungsang didiagnosis melalui palpasi, auskultasi, pemeriksaan dalam dan pemeriksaan penunjang seperti ultrasonografi (USG). ${ }^{(1)}$ Kehamilan letak sungsang terjadi pada 3-4\% kehamilan dimana $25 \%$ pada usia kehamilan 28 minggu, $7 \%$ pada minggu ke 32 dan 1-3 \% pada kehamilan cukup bulan. Angka tersebut akan turun seiring dengan umur kehamilan mendekati 40 minggu. ${ }^{(2)}$ Faktor penyebab letak sungsang yaitu kehamilan premature, malformasi rahim atau fibroid, polihidramnion, plasenta previa, kelainan janin (hidrochepalus, anenchepalus, malformasi SSP, massa leher, aneuploidi), dan

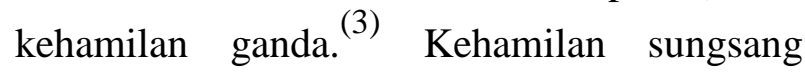
menyebabkan resiko morbiditas dan mortalitas yang tinggi. Sebagian besar kehamilan sungsang berakhir dengan operasi Caesar. Pada kehamilan dengan letak kepala, bagian kepala yang merupakan bagian terbesar janin lahir terlebih dahulu, sedangkan pada letak sungsang bagian terbesar janin akan lahir terakhir. Persalinan kepala pada letak sungsang tidak mempunyai mekanisme "Maulage" karena susunan tulang dasar kepala yang rapat dan padat, sehingga hanya mempunyai waktu 8 menit, setelah badan bayi lahir. Keterbatasan waktu persalinan kepala dan tidak mempunyai mekanisme maulage dapat menimbulkan kematian bayi yang besar. $^{(4)}$ Menurut WHO, 99\% kematian ibu akibat masalah persalinan terjadi di negaranegara berkembang termasuk di Indonesia. Angka kematian Ibu di Indonesia tercatat menduduki peringkat kedua se Asia, dimana pada tahun 2015 tercatat 23/100.000 kelahiran hidup. ${ }^{(5)}$ Angka kematian bayi pada persalinan sungsang lebih tinggi dibandingkan dengan letak kepala. Angka kematian perinatal dengan kehamilan sungsang di Indonesia sekitar 16,8 $38,5 \%$. Presentasi sungsang terjadi dalam 3$4 \%$ dari seluruh persalinan. ${ }^{(6)}$ Penelitian Greenhill melaporkan kejadian persalinan presentasi sungsang sebanyak 4-4,5\%. Di Parkland Hospital dari tahun 1990-1999 dari 136.256 persalinan normal sebanyak 3,5\% merupakan presentasi sungsang. Pada tahun 1990 sebanyak 90\% kasus letak sungsang dilahirkan secara perabdominam, sedangkan pada tahun 1970 hanya sebanyak 11,6\%. Di Hongkong, operasi perabdominam sudah menjadi indikasi kehamilan sungsang. Persentase persalinan sungsang secara pervaginam telah menurun dari tahun 1998 dari $12,08 \%$ menurun menjadi $5,28 \%$ pada tahun 2008. Di Perancis dilaporkan 16,3\% pada tahun 1999 sebanyak 16,3\%, pada tahun 2001 sebanyak $17,6 \%$, pada tahun 2003 18,7\%, dan pada tahun 2005 sebanyak 19,2\%. Di Swedia, pada tahun 1999 persalinan sungsang dengan perabdominam sebanyak 75,3\% meningkat pada tahun 2001 sebanyak $86,0 \%{ }^{(7)}$ Karena jumlah persalinan letak sungsang secara perabdominam meningkat, terdapat peningkatan juga terhadap angka morbiditas maternal. Pertolongan persalinan sungsang melalui pervaginam memerlukan perhatian karena dapat menimbulkan komplikasi kesakitan, cacat permanen sampai dengan kematian bayi. ${ }^{(8)}$ Pada ibu hamil letak sungsang dengan indikasi belum pernah SC, kehamilan sudah cukup bulan dan taksiran berat janin besar maka dianjurkan melakukan persalinan perabdominam. ${ }^{(7)}$ Menurut penelitian Lia Yulianti tahun 2014 dalam Silvika (2019), menyatakan bahwa dari 189 kasus $(88,33 \%)$ persalinan, angka mortalitas akibat persalinan letak sungsang sebanyak 15 kasus (7\%), morbiditas 10 kasus $(4,6 \%)$ sedangkan sebagian kasus tidak dijelaskan. Mortalitas kasar pada janin berkisar 10-20\%. Penyebab utama kematian bayi adalah 
prematuritas. Resiko untuk janin pada presentasi bokong lebih besar dibandingkan dengan presentasi kepala. Berdasarkan indikasi bayi, diketahui lebih dari separuh $(52,3 \%)$ persalinan caesarea elektif dilakukan karena letak sungsang/malposisi sedangkan pada caesarea emergensi lebih dari sepertiga responden $(37,8 \%){ }^{(10)}$ Adanya berbagai risiko pada persalinan sungsang dan operasi caesar, maka dipromosikan beberapa manuver versi janin menuju presentasi kepala. ${ }^{(11)}$ Beberapa teknik untuk mengurangi insiden morbiditas ibu yang masih sering digunakan yaitu posisi knee-chest, Eksternal Cephalic Version (ECV) dan akhirakhir ini muncul metode baru di China yang dikenal dengan pengobatan / terapi moksibusi. ${ }^{(12)}$ Moksibusi (Moxa) merupakan praktek pembakaran ramuan mugwort (armetisia vulgaris) melalui titik akupuntur kandung kemih (BL) 67 yang terletak di bagian luar jari kelingking kaki dan diletakkan dekat dengan kulit sampai menghasilkan hiperemi dari vasodilatasi lokal. ${ }^{(11)}$ Bahan-bahan moxa terdiri lebih dari 60 jenis komponen, salah satunya minyak atsiri dari moxa termasuk 1,8-Cineole, alkena thujene alpha, pinene, sabinene, dll), kamper, borneol, dan aldehida kecil, keton, fenol, alkana, dan seri senyawa benzena. Heptatriacontane $\left(\mathrm{C}_{37} \mathrm{H}_{76}\right)$ memainkan peran penting dalam pembakaran. Moxa juga memiliki tanin, flavonoid, sterol, polisakarida, elemen, dan bahan-bahan lainnya. Tingkat minyak atsiri dari moxa adalah $0,45 \% \quad-1,00 \%$ dengan berbagai kegiatan biologis yang bermanfaat seperti perluasan otot polos saluran napas, menghilangkan batuk, efek ekspektoran, dan aktivitas antioksidan yang kuat karena kaya akan flavonoid dan polisakarida. ${ }^{(13)}$ Terapi Moxa sudah lama dikenal dan digunakan pada pengobatan tradisional Cina lebih dari 3.000 tahun. Namun penelitiannya mulai dilakukan pada tahun 80/90-an. Studi yang dipublikasikan pada artikel JAMA (1998) menyatakan bahwa penelitian pada 260 ibu hamil, 50\% diberikan terapi moxibustion, dan
$50 \%$ tidak diberikan terapi moxa. Setelah diobservasi selama 2 minggu, responden yang diberikan terapi moxa mengalami perubahan yaitu janin telah beralih ke posisi yang tepat (sefalika) sebanyak 74,8\%, sedangkan responden yang tidak diberikan terapi hanya 47,7\%. Studi ini juga menunjukkan adanya peningkatan gerakan pada janin dengan pemberian terapi moxa dibandingkan dengan ibu tanpa terapi moxa. ${ }^{(12)}$

Ketika ibu hamil didiagnosa sungsang, muncul rasa takut, cemas\&khawatir terhadap kesejahteraan janin terutama terhadap proses persalinan. Sejak didalam rahim, bayi merupakan bagian dari ibu sehingga apapun pikiran \& perasaan ibu hamil masih sangat terhubung dengan bayinya, maka masih sangat mudah untuk diajak komunikasi dan diberikan sugesti. (1) Hypnobirthing merupakan salah satu cara untuk memberikan sugesti dan mereprograming pikiran bawah sadar, yang dapat diarahkan untuk membuat perubahan dalam tubuh ibu. Pada hypnobirthing digunakan teknik pelepasan ketakutan dengan tujuan membantu ibu rileks dan memungkinkan bayi berputar. Dalam sebuah penelitian Mehl LE (1994), dalam Arch Fam Med "Hypnosis and conversion of the breech to the vertex presentation" Department of Psychiatry, University of Vermont College of Medicine, Burlington, menyatakan bahwa angka keberhasilan bayi bisa berubah ke posisi kepala dengan hypnobirthing sekitar $81 \%$ dan dilakukan pada usia 34 hingga 37 minggu. ${ }^{(2)}$

Tujuan penelitian ini untuk mengetahui efektifitas terapi moxa dan hypnobirthing serta mengetahui metode yang paling efektif terhadap perbaikan letak sungsang pada ibu hamil Trimester III . Keutamaan penelitian ini adalah menghasilkan analisis tentang efektifitas pemberian terapi moxa dan hypnobirthing sehingga hasilnya dapat digunakan untuk kebaruan ilmu kebidanan 
tentang penatalakasanaan perubahan letak janin pada kehamilan sungsang.

\section{TINJAUAN PUSTAKA}

Persalinan letak sungsang adalah persalinan pada bayi dengan presentasi bokong (sungsang) dimana bayi letaknya sesuai dengan sumbu badan ibu, kepala berada pada fundus uteri, sedangkan bokong merupakan bagian terbawah di daerah pintu atas panggul atau simfisis. ${ }^{(14)}$ Patofisiologi kehamilan sungsang yaitu pada kehamilan < 32 minggu, jumlah air ketuban relative lebih banyak, sehingga memberikan kesempatan pada janin untuk bergerak bebas sehingga janin dapat menempatkan diri dalam presentasi kepala, letak sungsang, maupun letak lintang. Pada kehamilan trimester III janin tumbuh dengan cepat dan jumlah air ketuban berkurang sehingga posisi bokong dengan kedua tungkai yang terlipat lebih besar daripada kepala, maka bokong dipaksa menempati ruang yang lebih luas yaitu di fundus uteri, sedangkan kepala berada didalam ruangan yang lebih kecil yaitu di segmen bawah uterus. ${ }^{(15)}$ Dapat disimpulkan bahwa pada kehamilan kurang bulan, kehamilan letak sungsang lebih tinggi, sedangkan pada kehamilan cukup bulan sebagian besar janin pada presentasi kepala. Kejadian presentasi sungsang pada usia kehamilan 28 minggu sebanyak 20\%, meskipun versi spontan sering terjadi, sehingga hanya $3-4 \%$ wanita dengan kehamilan tunggal cukup bulan yang janinnya dalam presentasi sungsang. ${ }^{(3)}$ Dengan adanya presentasi bokong, ibu memiliki resiko lebih besar untuk terjadinya komplikasi selama proses persalinan dibandingkan presentasi kepala. Komplikasi yang terjadi pada ibu yaitu perdarahan, robekan jalan lahir dan infeksi. Sedangkan komplikasi yang terjadi pada janin adalah asfiksia, trauma persalinan, infeksi, aftercoming head. ${ }^{(4)}$ Resiko untuk janin pada presentasi bokong lebih besar dibandingkan dengan presentasi kepala. Komplikasi yang terjadi pada ibu akibat letak sungsang dengan adanya manipulasi manual di dalam jalan lahir akan meningkatkan risiko infeksi pada ibu, perasat-perasat intrauterine terutama pada segmen bawah rahim uterus yang menipis atau pelahiran afteroming head pada serviks yang belum membuka penuh dapat mengakibatkan rupturuteri, laserasi serviks atau keduanya. Manipulasi seperti ini dapat memperluas episiotomy dan robekan perineum yang dalam ketuban pecah spontan mungkin saja tali pusat ikut keluar (prolapsus tali pusat), jika tidak segera dilakukanan persalinan, janin mungkin tidak diselamatkan, untuk mencegahnya persalinan dapat dilakukan dengan cara seksio caesaria. ${ }^{(9)}$ Beberapa manuver dipromosikan untuk mengubah letak sungsang menjadi kepala yaitu dengan pemberian terapi moxa dan hypnobirthing. Terapi moxa mampu meningkatkan aktivitas janin sehingga janin mampu berotasi dari presentasi bokong menjadi presentasi kepala. Studi yang dilakukan di Cina dilaporkan angka keberhasilan menggunakan terapi moxa berkisar antara 80,9\% - 90,3\%. Sebagian besar penelitian menyatakan bahwa waktu yang optimal \& menghasilkan angka keberhasilan yang tinggi dalam terapi moxa pada usia kehamilan 34 minggu. ${ }^{(12)}$ Penelitian di Inggris \&Wales menyatakan bahwa sekitar 670,000 bayi lahir setiap tahunnya dan sekitar 23.450 $(3,5 \%)$ tetap dalam posisi sungsang. Untuk menghindari risiko melahirkan sungsang sebagian besar akan melahirkan dengan operasi Caesar. ${ }^{(1)}$ Penelitian yang diterbitkan pada artikel JAMA menunjukkan bahwa terapi moxa memberikan kesempatan pada bayi untuk berputar secara spontan antara usia kehamilan 33-37 minggu dari 50\% menjadi $75 \%$. Ibu hamil dapat memulai terapi moxa pada usia kehamilan 33 minggu. Artikel dalam Journal American Cina Medicin (2001) menyatakan bahwa ibu hamil yang menerima moxa-terapi pada usia kehamilan 28 minggu akan memberikan tingkat keberhasilan yang lebih tinggi yaitu posisi janin berubah $92,48 \%$ dan ibu tanpa terapi moxa sebesar $73,66 \%$. $^{(13)}$ Moxibustion adalah praktik pembakaran daun mugwort (stik moxa) pada titik-titik akupunktur BL 67 atau Zhi Yin di kaki 
menghasilkan energi YANG (energi pemanasan) pada dasar panggul. Hasil penelitian pada tahun 1987 menyatakan bahwa wanita yang melakukan moxibustion, posisi janin berubah $>36 \%$. Efek samping atau kerugian tidak ditemukan sehingga tidak menimbulkan risiko. Usia kehamilan 34-36 minggu paling efektif dilakukan terapi moxa. ${ }^{(17)}$ Hypnobirthing merupakan salah satu teknik otohypnosis (self hypnosis), yaitu upaya dalam menanamkan niat positif/sugesti kedalam jiwa atau pikiran bahwa sadar dalam menjalani masa kehamilan dan persiapan persalinan. Dengan demikian ibu hamil dapat menikmati indahnya masa kehamilan dan lancarnya proses kehamilan. ${ }^{(17)}$ Metode hypnobirthing didasarkan pada keyakinan bahwa setiap perempuan memiliki potensi untuk menjalankan proses melahirkan secara alami, tenang dan nyaman. Hypnobirthing memberikan sugesti dan mereprograming alam bawah sadar, yang mampu diarahkan untuk membuat perubahan dalam tubuh ibu. Pada terapi hipnobirthing digunakan teknik pelepasan ketakutan sehingga membantu ibu tenang, nyaman dan memberikan kesempatan pada bayi untuk berputar. (1) Manfaat hypnobirthing selama kehamilan yaitu dapat mengurangi rasa mual,muntah, dan pusing pada trismester pertama, meminimalkan trauma secara fisik dan jiwa untuk ibu dan janin, mengatasi rasa tidak nyaman selama hamil dan rasa sakit saat melahirkan tanpa efek samping terhadap janin, membantu janin terlepas dari kondisi lilitan tali pusat, memperbaiki janin yang letaknya sungsang menjadi normal dan juga bisa membuat kondisi ibu hamil menjadi tenang dan damai selama kehamilannya. Ketenangan dan rasa damai sang ibu akan dirasakan pula oleh janin. ${ }^{(17)}$ Hipnoterapi biasanya mengambil pendekatan dua arah untuk memutar bayi. Pertama, ibu akan dihipnotis ke dalam keadaan relaksasi yang mendalam. Hal ini membantu otot-otot panggul mengendur dan bagian bawah rahimnya mengembang sehingga mendorong bayi untuk berputar. Kedua, ibu bayi akan diarahkan ke teknik visualisasi untuk membayangkan bayi berputar ke arah yang berlawanan. ${ }^{(2) .}$ Hasil penelitian Mehl LE (1994), dalam Arch Fam Med "Hypnosis and conversion of the breech to the vertex presentation" Department of Psychiatry, University of Vermont College of Medicine, Burlington, menyatakan bahwa angka keberhasilan bayi bisa berubah ke posisi kepala dengan hypnobirthing sekitar $81 \%$ dan dilakukan pada usia 34 hingga 37 minggu. ${ }^{(2)}$

\section{METODE}

Penelitian ini merupakan penelitian eksperimen murni (true experimental) dengan pendekatan post test control design. Dalam eksperimen murni semua variabel yang akan diuji pengaruhnya, dikontrol atau disamakan karakteristiknya. Variabel-variabel tersebut diuji dan diukur perubahannya dengan cara membandingkan kondisi awal sampel sebelum diberikan perlakuan dengan kondisi akhir sampel setelah diberikan perlakuan. ${ }^{(18)}$ Sampel pada penelitian ini adalah ibu hamil pada trimester III dengan kriteria inklusi yaitu ibu hamil yang bersedia menjadi responden penelitian, ibu dengan presentasi bokong, usia kehamilan 32-37 minggu. Kriteria eksklusi meliputi ibu dengan penyulit kehamilan (Tali Pusat pendek, Polihidramnion, CPD), serta Gawat janin (DJJ $<100 x / m e n i t$ dan $>160 x /$ menit). Pemilihan sampel dilakukan dengan simple randomized sampling, karena ketiga kelompok tersebut sudah dianggap representative dan memiliki hak yang sama untuk semua posisi dalam penelitian. Jumlah sampel yang diperlukan untuk tiap kelompok sebanyak 9 orang, sehingga total sample 27 orang. Untuk mengantisipasi drop out responden, maka ditambahkan $20 \%$ sehingga diperoleh total 33 responden yang terbagi dalam tiga kelompok. ${ }^{(19)}$ Variabel bebas dalam penelitian ini adalah perlakuan yang diberikan pada pada kelompok terapi moxa dan terapi hypnobirthing. Variabel terikat adalah hasil pemberian perlakuan berupa perubahan letak bokong menjadi kepala, sedangkan variabel kontrol adalah kelompok yang tidak diberikan perlakuan. Pengumpulan data dilakukan selama 2 bulan. Perlakuan dilakukan di klinik Praktik Mandiri Bidan wilayah Kabupaten 
Bandung Barat.

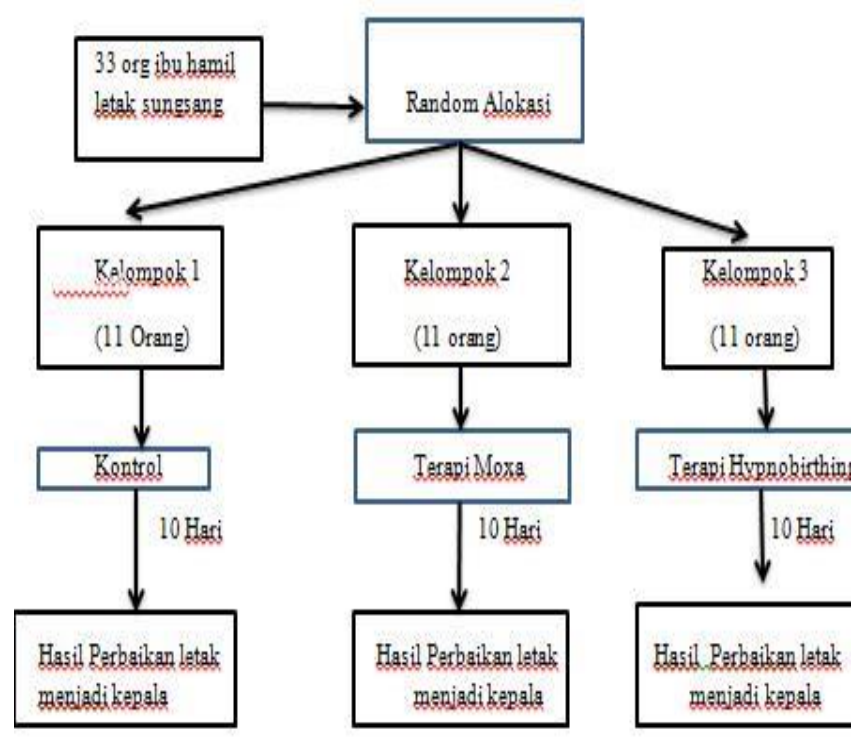

Gambar 3.2 Alur Penelitian

Analisis data menggunakan uji krusskall-walis, dimana hasil uji normalitas data didapatkan bahwa salah satu data terdistribusi tidak normal maka tidak memenuhi syarat untuk uji parametrik. ${ }^{(18)}$ Terapi moxa dilakukan dengan cara menghangatkan titik akupunktur di

BL 67 di sudut luar jari kelingking kaki menggunakan stik moxa dengan jarak minimal I cm (1/3 inci) selama 15 menit. Terapi ini diulang selama 10 hari berturut-turut di waktu malam hari sebelum tidur agar ibu lebih rileks dalam meakukan terapi moxa. Terapi hypnobirthing dilakukan dengan cara memberikan sugesti pada ibu untuk membuat bayinya berputar dengan diringi music hypnoterapi. Terapi dilakukan dengan posisi yang nyaman bagi ibu biasanya dengan cara berbaring, ibu memejamkan mata sambil diarahkan untuk membayangkan bayinya berputar. Terapi dilakukan selama 15 menit. Setelah 10 hari, masing-masing terapi di observasi hasilnya dan ditarik kesimpulan.

HASIL DAN PEMBAHASAN

Tabel Distribusi Frekwensi Karakteristik Ibu

\begin{tabular}{lll}
\hline Umur & $\mathrm{F}$ & $\%$ \\
\hline$<20$ tahun & 1 & 3 \\
\hline $20-35$ tahun & 30 & 90,9 \\
\hline$>35$ tahun & 2 & 6,1 \\
\hline Total & $\mathbf{3 3}$ & $\mathbf{1 0 0}$ \\
\hline Paritas & $\mathrm{F}$ & $\%$ \\
\hline Primipara & 9 & 27,3 \\
\hline Multipara & 22 & 66,7 \\
\hline Grande Multipara & 2 & 6,1 \\
\hline Total & $\mathbf{3 3}$ & $\mathbf{1 0 0}$ \\
\hline Usia Kehamilan & $\mathrm{F}$ & $\%$ \\
\hline Premature & 31 & 93,9 \\
\hline Matur & 2 & 6,1 \\
\hline Total & $\mathbf{3 3}$ & $\mathbf{1 0 0}$ \\
Sumber: Wiknjosastro, 2008, hasil penelitian 2020
\end{tabular}

Sumber : Wiknjosastro, 2008, hasil penelitian 2020

Tabel diatas menunjukan bahwa karakteristik Ibu hamil berdasarkan umur yaitu terdapat Ibu hamil dengan umur < 20 tahun sebanyak 1 orang $(3 \%)$ dan kelompok ibu dengan umur $>35$ tahun sebanyak 2 orang $(6,1 \%)$, berdasarkan paritas sebagian besar ibu berada pada paritas multipara yaitu mempunyai anak (2-4 anak) sebanyak 22 orang $(66,7 \%)$, berdasarkan usia kehamilan terdapat ibu dengan usia kehamilan matur (usia kehamilan 37 - 42 minggu) sebanyak 2 orang $(6,1 \%)$. Berdasarkan hasil penelitian, terapi moxa lebih efektif diberikan pada ibu hamil dengan usia kehamilan antara 34-36 minggu. 
Tabel Perbandingan Kelompok Sebelum diberikan Intervensi dan Setelah Diberikan Intervensi

\begin{tabular}{|c|c|c|c|c|c|c|c|c|c|c|c|c|c|c|}
\hline \multirow[b]{2}{*}{ Terapi } & \multicolumn{6}{|c|}{$\mathrm{H} 1$} & \multicolumn{6}{|c|}{$\mathrm{H} 10$} & \multirow{2}{*}{$\begin{array}{c}\mathrm{P} \\
\text { value }\end{array}$} & \multirow{2}{*}{$\begin{array}{l}\text { Mean } \\
\text { Rank }\end{array}$} \\
\hline & Sungsang & $\%$ & $\begin{array}{l}\text { Letak } \\
\text { kepala }\end{array}$ & $\%$ & Total & $\%$ & Sungsang & $\%$ & $\begin{array}{l}\text { Letak } \\
\text { kepala }\end{array}$ & $\%$ & Total & $\%$ & & \\
\hline Kontrol & 11 & $\begin{array}{c}10 \\
0\end{array}$ & 0 & 0 & 11 & $\begin{array}{c}10 \\
0\end{array}$ & 10 & 90,9 & 1 & 9,1 & 11 & $\begin{array}{c}10 \\
0\end{array}$ & & 10.50 \\
\hline Moxa & 11 & $\begin{array}{c}10 \\
0\end{array}$ & 0 & 0 & 11 & $\begin{array}{c}10 \\
0\end{array}$ & 0 & 0 & 11 & $\begin{array}{c}10 \\
0\end{array}$ & 11 & $\begin{array}{c}10 \\
0\end{array}$ & 0,000 & 25.50 \\
\hline $\begin{array}{l}\text { Hypnobirthin } \\
\mathrm{g}\end{array}$ & 11 & $\begin{array}{c}10 \\
0\end{array}$ & 0 & 0 & 11 & $\begin{array}{c}10 \\
0\end{array}$ & 7 & 63,6 & 4 & $\begin{array}{c}36 \\
4\end{array}$ & 11 & $\begin{array}{c}10 \\
0\end{array}$ & 0,000 & 15.00 \\
\hline Total & 33 & $\begin{array}{c}10 \\
0\end{array}$ & $\mathbf{0}$ & $\overline{\mathbf{0}}$ & 100 & $\begin{array}{c}10 \\
\mathbf{1 0}\end{array}$ & 17 & 51,5 & 16 & $\begin{array}{c}48, \\
5\end{array}$ & 100 & $\begin{array}{c}10 \\
0\end{array}$ & & \\
\hline
\end{tabular}

Berdasarkan tabel diatas didapatkan perbedaan sebelum dan setelah diberikan intervensi, dimana sebelum diberikan intervensi seluruh ibu hamil dengan letak sungsang. Setelah diberikan intervensi selama 10 hari, diketahui bahwa untuk kelompok kontrol dari 11 orang ibu hamil yang berubah letak janinnya menjadi letak kepala yaitu 1 orang $(9,1 \%)$, pada kelompok dengan pemberian intervensi terapi Moxa seluruh ibu hamil mengalami perubahan letak janin menjadi kepala sebanyak 11 orang (100\%), pada kelompok terapi hypnobirthing, terdapat ibu hamil yang mengalami perubahan letak janin menjadi kepala yaitu 4 orang ( $36,1 \%)$ dengan nilai $\mathrm{p} 0,001(\mathrm{p}<0,005)$ artinya pemberian terapi Moxa dan hypnobirthing efektif untuk perbaikan letak sungsang pada ibu hamil Trimester 3. Hasil penelitian ini sejalan dengan hasil penelitian yang dilakukan di Cina bahwa angka keberhasilan menggunakan terapi moxa berkisar antara 80,9\% - 90,3\%. Sebagian besar penelitian menyatakan bahwa waktu yang optimal \& menghasilkan angka keberhasilan yang tinggi dalam terapi moxa pada usia kehamilan 34 minggu. $^{(12)}$ Penelitian di Inggris \&Wales menyatakan bahwa sekitar 670,000 bayi lahir setiap tahunnya dan sekitar $23.450(3,5 \%)$ tetap dalam posisi sungsang. ${ }^{(1)}$ Penelitian ini juga didukung oleh penelitian yang diterbitkan pada artikel JAMA bahwa terapi moxa memberikan kesempatan pada bayi untuk berputar secara spontan antara usia kehamilan 33-37 minggu dari $50 \%$ menjadi $75 \%$. Ibu hamil dapat memulai terapi moxa pada usia kehamilan 33 minggu. Artikel dalam Journal American Cina Medicin (2001) menyatakan bahwa ibu hamil yang menerima moxa-terapi pada usia kehamilan 28 minggu akan memberikan tingkat keberhasilan yang lebih tinggi yaitu posisi janin berubah 92,48\% dan ibu tanpa terapi moxa sebesar $73,66 \%$. $^{(13)}$ Penelitian pada kelompok hypnobirthing menyatakan bahwa terapi ini memberikan kesempatan pada letak sungsang menjadi kepala. Hal ini sejalan dengan penelitian $L E$ (1994), "Hypnosis and conversion of the breech to the vertex presentation" Department of Psychiatry, University of Vermont College of Medicine, Burlington, menyatakan bahwa angka keberhasilan bayi bisa berubah ke posisi kepala dengan hypnobirthing sekitar $81 \%$ dan dilakukan pada usia 34 hingga 37 minggu. ${ }^{(2)}$ Berdasarkan efektifas terapi yang diberikan, maka terapi Moxa merupakan terapi yang paling efektif diberikan terhadap ibu hamil untuk perbaikan letak sungsang dengan nilai mean (25.50) lebih besar dibandingkan dengan terapi hypnobirthing dengan nilai (mean 15.00). Hasil penelitian ini sejalan dengan penelitian yang dipublikasikan dalam artikel JAMA (1998) yang menyatakan bahwa penelitian pada 260 ibu hamil, dimana 50\% diberikan terapi moxibustion, dan 50\% tidak diberikan terapi moxa. Setelah diobservasi selama 2 minggu, responden yang diberikan terapi moxa mengalami perubahan yaitu janin telah beralih ke posisi yang tepat (sefalika) sebanyak $74,8 \%$, sedangkan responden yang tidak diberikan terapi hanya 47,7\%. Tidak dilaporkan adanya efek samping atau kerugian sehingga tidak berisiko. Terapi moxibustion merupakan terapi yang paling efektif dibandingkan dengan terapi hypnobirthing. ${ }^{(20)}$ 


\section{KESIMPULAN}

Berdasarkan hasil penelitian yang telah dilakukan bahwa terapi moxa dan hypnobirthing sama-sama efektif dalam perbaikan letak sungsang pada ibu hamil trimester III. Terapi 7. moxa merupakan metode yang paling efektif di diberikan dibandingkan dengan hypnobirthing. Peneliti percaya bahwa terapi moxa merupakan alternative pilihan yang representative dan dapat di pertimbangkan sebagai salah satu teknik untuk membantu versi janin dengan presentasi sungsang.

\section{DAFTAR PUSTAKA}

1. Aprillia, Y. 2013. Berbagai Pilihan Tuk Rubah Posisi Sungsang Menjadi Letak Kepala. [Online]. Tersedia :http://www.bidankita.com/index.ph $\mathrm{p}$ ?opt

ion $=$ com_content $\&$ view $=$ article $\&$ id =628:ubah-sungsang-jadi-

kepala\&catid $\quad=40$ : $m o n$ thlyguide \&Itemid $=34[$ Diakses $\quad: \quad 7$ Mei 2020].

2. Aprillia, Y. 2012. Moxibution \& Hypnobirthing untuk Kehamilan Sungsang. [Online]. Tersedia : http://www.bidankita.com/index.php ?option=com_content\&view=article \&id=493: moxibution-a-hypnobirthinguntukkehamilansungsang\&catid $=44$ : naturalchildbir th\& Itemid=56 [Diakses : 7 Mei 2020].

3. Richard Fischer, MD. Breech Presentation. Juli 2012. [Online].

Tersedia : http://emedicine.medscape.com. [Diakses : 12 Juli 2020].

4. Manuaba, Ida Ayu. 2010. Ilmu Kebidanan, Penyakit kandungan dan KB. Edisi 2. EGC. Jakarta.

5. Joewono BN. Angka kematian ibu, 228/100.000 kelahiran hidup. [cited 22 Jan 2021]. Available from: http://www.lipsus.kompas.com/hidayatdi $\mathrm{dik} / \mathrm{read} / 2012 / 01 / 31 / 22093816 /$ Angka.K ematian.Ibu.228/100.000.Kelahiran.Hidu p; 2012

6. Fisher

$\mathrm{R}$.

Breech
Presentation.Philadelphia: Available from:

http://emedicine.medscape.com/article/2 62159-0verview; 2016

Demirci O, Tuğrul AS, Turgut A, Ceylan Ş, Eren S. Pregnancy outcomes by mode of delivery among breech births. Arch Gynecol Obstetr;285:297-303; 2012

8. Cunningham FG, Leveno KJ, Bloom SL, Hauth JC, Rouse, Spong CY. Obstetri Willaims. 23rd ed. United States of America:The McGraw Hill Companies.; 2014

9. S Silvika. 2019. Asuhan keperawatan pada ibu hamil resiko tinggi kelainan letak presentasi bokongserta pengaruh evidence based practice nursing di wilayah kerja Puskesmas Lubuk Buayaa

Padang. Tersedia:

http://scholar.unand.ac.id/54222/2/BAB \%20I.pdf. [Diakses : 20 Januari 2021].

10. Putri, N. (2017) Perbandingan Karakteristik Ibu dan Luaran Perinatal pada Presentasi Sungsang Antara Persalinan Pervaginam dan Persalinan Perabdominam di RSUD Cibabat Periode Januari 2015 - Desember 2016. Undergraduate thesis, Universitas Kristen Maranatha.

11. Vas J, Aranda JM, Aranda JM, Modesto M, Ramos M, Baron M, Using moxibustion in primary healthcare to correct non-vertex

presentation: a multicentre randomized controlled trial. Acupunct Med 2013; 31-38.

12. Cardini, $F$ et al. 1998. Moxibustion forCorrectionofBreech Presentation:aRandomized Controlled Trial. J. JAMA. 280(18):1580-4.

3. Neri, I., Pace, V.D., Venturini, P., Facchinetti, F. 2007. Effects of

ThreeDifferentStimulations (Acupuncture, Moxibustion, Acupuncture Plus Moxibustion) of BL.67 Acupoint at Small Toe on Fetal Behavior of Breech Presentation. The American Journal of Chinese Medicine, Vol. 35, No. 1, 27-33 
14. Didien IS, dkk. 2016. Modul Bahan Ajar Cetak Kebidanan Asuhan

KebidananKegawatdaruratan

MaternalNeonatal.Jakarta:

PPSDMK.

15. Wiknjosastro, Hanifa. 2008. Ilmu

Kebidanan.Jakarta:Yayasan

BinaPustaka Sarwono

Prawirohardjo.

16. Hadikusumo, B.U. 1996. Tusuk

Jarum Upaya Penyembuhan

Alternatif. Ed 8. Yogyakarta:

Penerbit Kanisius.

17. Kuswandi, Lanny. (2013). Hypnobirthing, A Gentle Way to Give Birth. Jakarta: Pustaka Bunda

18. Dahlan, M. Sofiyudin. 2013. Statistik Untuk Kedoketran dan Kesehatan. Jakarta : Salemba Medika

19. Supranto J. Teknik sampling untuk survey dan eksperimen. Jakarta: PT Rineka Cipta; 2000.

20. Kusuma, P. D. (2013). Moxibustion Sebagai Terapi Untuk Membantu Versi / Pemutaran Pada Janin Dengan Presentasi Sungsang : Studi Literatur. 
